\title{
Divergent selection towards body weight and betaine supplementation on quails performance in tropical environment
}

\author{
Adi Ratriyanto ${ }^{1,2^{*}}$, Nuzul Widyas ${ }^{2}$, Sigit Prastowo ${ }^{1,2}$, and Dafa Feron Andrianto ${ }^{1}$ \\ ${ }^{1}$ Department of Animal Science, Faculty of Agriculture, Universitas Sebelas Maret, Surakarta 57126, \\ Indonesia \\ ${ }^{2}$ Center for Biotechnology and Biodiversity Research and Development, Universitas Sebelas Maret, \\ Surakarta 57126, Indonesia
}

\begin{abstract}
Initial body weight may affect animal performance. This study investigated the effect of divergent selection based on body weight and betaine supplementation on performance of quails in the tropical environment. In total, 900 7-day-old female Japanese quails were divided into 30 cages of 30 birds in a $3 \times 2$ factorial design. The first factor was body weight (Random, High, and Low), and the second factor was betaine supplementation $(0 \%$ and $0.14 \%)$, resulting in 6 treatments. Performance data were collected for 2 periods of 28 days during the laying phase. The variables observed included feed consumption, egg production, egg weight, and feed conversion. The data were analyzed using analysis of variance and continued with Duncan's Test for significant results. The results showed that there was no interaction between body weight and betaine supplementation on quails' performance. Random body weight produced more eggs and the highest feed efficiency than Low body weight $(\mathrm{P}<0.05)$, although the result did not differ from High body weight. Betaine supplementation enhanced egg weight $(\mathrm{P}<0.05)$ than the non-supplemented group but did not affect other variables. It is concluded that Random and High weight and betaine supplementation can be applied to optimize the performance of quails in a tropical environment.
\end{abstract}

\section{Introduction}

Laying quail (Coturnix coturnix japonica) is one of the potential egg producers, reaching 250-300 eggs per year [1]. The quails raised by the farmers in Indonesia commonly originated from various smallholder breeders; thus, the information about the genetics of quail circulating is still unclear. This further leading to a high variation of productive performance, particularly egg production rate.

Quail productivity and metabolism rate are influenced by the feed and nutrients consumed. The high variation indicates that the metabolic rate of each individual in the quail population is not uniform, which greatly affects the response of each individual to the feed given. Hence, its presence needs to be minimized. One of the methods to reduce variation in

* Corresponding author: ratriyanto@staff.uns.ac.id 
quail populations is by conducting divergent selection based on body weight [2]. Divergent selection is performed by grouping the quails into specific bodyweight clusters, for example, high, low, and random body weight $[3,4]$. Selection based on body weight was used as an indicator of metabolic rate. Differentiating body weight is expected to minimize the bodyweight variation and to increase quail productivity [5].

Furthermore, quail productivity can be optimized by feed additive supplementation that can increase protein and energy metabolism, such as betaine. Betaine is a potential organic osmolyte, and a methyl group donor that can improve nutrient digestibility and metabolism leads to optimal livestock performance [6,7].

A previous study revealed that body weight selection affects feed consumption, egg production, and egg weight of Japanese quails [3]. Meanwhile, the application of betaine in poultry diets has improved performance traits in both meat-type and laying poultry. For instance, studies in ducks [8] and broiler chicken [9] showed that betaine supplementation enhanced feed intake and body weight and reduced feed conversion. In laying poultry, betaine improved the feed intake, egg production, and protein and energy efficiency ratio in quails [7] and chickens [10]. However, there is lacking information on the optimal body weight cluster for egg production purposes. Moreover, no studies have been performed on betaine supplementation to quails selected divergently based on body weight. Therefore, the purpose of this study was to determine the effect of divergent selection of body weight and betaine supplementation on the productive performance of laying quails.

\section{Materials and methods}

\subsection{Experimental design and diets}

The experiment used 900 seven-day-old female quails (Coturnix coturnix japonica) obtained from a quail breeder in Karanganyar, Central Java. They were divided into 30 cages of 30 birds in a $3 \times 2$ factorial design. The first factor was body weight (Random, High, and Low), and the second factor was betaine supplementation $(0 \%$ and $0.14 \%)$, resulting in total combination 6 treatments. The three bodyweight clusters consisted of Random body weight (RBW, average body weight $20.33 \pm 1.46 \mathrm{~g}$ ), High body weight (HBW, 23.01 $\pm 1.66 \mathrm{~g}$ ), and Low body weight $(\mathrm{LBW}, 17.60 \pm 1.61 \mathrm{~g})$. Each treatment consisted of five replicates of 30 birds since the birds were assigned to the cage at 10 days of age. The factorial design was chosen to determine the interaction between body weight and betaine supplementation.

The basal diets based on yellow corn and soybean meal contained 2,800 kcal $/ \mathrm{kg}$ of metabolizable energy as well as $22 \%$ crude protein for the starter diet and $20 \%$ crude protein for the layer diet as presented in Table 1 according to the National Research Council (NRC) for quail [11]. The other experimental diets were obtained by supplementing $0.14 \%$ betaine at the expense of rice bran [12]. The birds were housed in colony battery cages of the same size, namely $120 \mathrm{~cm}$ length, $30 \mathrm{~cm}$ width, and $25 \mathrm{~cm}$ height.

\subsection{Data collection}

The birds were fed the starter diets until 35 days of age. Then the diets were replaced with layer diets. The diets were given twice a day, namely at $07.00 \mathrm{~h}$ and $13.30 \mathrm{~h}$, each with the same proportion. Also, the birds had free access to water and feed. The performance data were observed for two periods of 28 days $(2 \times 28$ days $)$ started after the egg production has reached $50 \%$ hen day average. The feed intake, egg production, and egg weight were recorded daily, while feed efficiency was calculated by dividing the egg mass by feed intake. 
Table 1. Composition and nutrient contents of starter and layer basal diets

\begin{tabular}{|l|c|c|}
\hline \multirow{2}{*}{ Ingredient } & \multicolumn{2}{|c|}{ Proportion (\%) } \\
\cline { 2 - 3 } & Starter & Layer \\
\hline Maize (\%) & 42.30 & 44.20 \\
\hline Rice bran (\%) & 12.85 & 8.47 \\
\hline Wheat bran (\%) & 7.87 & 5.50 \\
\hline Soybean meal (\%) & 26.00 & 25.10 \\
\hline Fish meal (\%) & 8.70 & 7.00 \\
\hline Coconut oil (\%) & 0.86 & 2.55 \\
\hline DL-methionine (\%) & 0.07 & 0.03 \\
\hline Dicalcium phosphate (\%) & 0.00 & 0.40 \\
\hline Limestone (\%) & 0.80 & 6.20 \\
\hline Premix (\%) & 0.25 & 0.25 \\
\hline NaCl (\%) & 0.35 & 0.30 \\
\hline Nutrient content & 2801 & 2799 \\
\hline Metabolizable energy (kcal/kg) & 22.00 & 20.00 \\
\hline Crude protein (\%) & 4.72 & 5.67 \\
\hline Crude fat (\%) & 5.23 & 4.64 \\
\hline Crude fiber (\%) & 7.23 & 6.44 \\
\hline Crude ash (\%) & 0.91 & 3.25 \\
\hline Calcium (\%) & 0.41 & 0.42 \\
\hline Phosphorus (\%) & 1.30 & 1.17 \\
\hline Lysine (\%) & 0.50 & 0.41 \\
\hline Methionine (\%)
\end{tabular}

The energy efficiency ratio (EER) was calculated as grams of egg mass per $100 \mathrm{kcal}$ of metabolizable energy intake. In contrast, protein efficiency ratio (PER) was calculated as grams of egg mass per gram of protein intake [13].

\subsection{Data analysis}

The data were analyzed with analysis of variance to determine the effect of the treatments. The following mathematical model was applied: $Y_{\mathrm{ijk}}=\mu+\alpha_{\mathrm{i}}+\beta_{\mathrm{j}}+\alpha \beta_{\mathrm{ij}}+\varepsilon_{\mathrm{ijk}}$ where: $\mu=$ general mean, $\alpha_{\mathrm{i}}=$ effect of body weight, $\beta_{\mathrm{j}}=$ effect of betaine supplementation, $\alpha \beta_{\mathrm{ij}}=$ the interaction effect of body weight and betaine supplementation, and $\varepsilon_{\mathrm{ijk}}=$ an experimental error. The statistically different means were compared using Duncan's multiple range test at $\mathrm{P}<0.05$. All statistical analyses were conducted using the $\mathrm{R}$ version 3.5.3 [14].

\section{Results and discussion}

The effect of divergent selection based on body weight selection and betaine supplementation in the diet on the productive performance of quail is presented in Table 2. An interaction was identified between body weight and betaine supplementation on egg weight $(\mathrm{P}=0.046)$, but not for feed intake and production (Table 3). It seemed that betaine enhanced egg weight in all bodyweight clusters. This result indicated that betaine effectively improves the egg weight of quails, as reported in previous studies [7]. The mechanism in which betaine improved egg weight is due to its involvement in protein and energy metabolism, which provide more nutrients for egg formation, resulting in enhance egg weight. Previous observation showed that betaine supplementation increased egg components such as fat content [15]. Enhancement in egg weight is associated with enhanced egg weight components such as yolk, albumen, and eggshell [16]. 
Table 2. Effect of divergent selection based on body weight and betaine supplementation on performance of Japanese quail.

\begin{tabular}{|l|c|c|c|}
\hline \multicolumn{1}{|c|}{ Treatments } & $\begin{array}{c}\text { Feed Intake } \\
\text { (gram) }\end{array}$ & $\begin{array}{c}\text { Egg Production } \\
\text { (\%) }\end{array}$ & $\begin{array}{c}\text { Egg weight } \\
\text { (gram) }\end{array}$ \\
\hline \multicolumn{4}{|c|}{ Interaction between body weight and betaine supplementation } \\
\hline RBW $\times$ betaine $0 \%$ & $23.07 \pm 0.53$ & $58.62 \pm 2.22$ & $9.69 \pm 0.12^{\mathrm{c}}$ \\
\hline RBW $\times$ betaine $0.14 \%$ & $23.40 \pm 0.74$ & $56.73 \pm 2.89$ & $10.29 \pm 0.14^{\mathrm{a}}$ \\
\hline LBW $\times$ betaine $\%$ & $23.27 \pm 0.53$ & $51.65 \pm 1.33$ & $9.72 \pm 0.16^{\mathrm{c}}$ \\
\hline LBW $\times$ betaine $0.14 \%$ & $23.63 \pm 0.42$ & $53.35 \pm 6.20$ & $10.23 \pm 0.25^{\mathrm{a}}$ \\
\hline HBW $\times$ betaine $0 \%$ & $23.60 \pm 0.58$ & $54.45 \pm 4.28$ & $9.98 \pm 0.20^{\mathrm{b}}$ \\
\hline HBW $\times$ betaine $0.14 \%$ & $24.02 \pm 0.05$ & $57.00 \pm 1.67$ & $10.20 \pm 0.09^{\mathrm{a}}$ \\
\hline$P$ value & 0.982 & 0.344 & 0.046 \\
\hline Effect of body weight & $23.24 \pm 0.63$ & $57.67 \pm 2.62^{\mathrm{a}}$ & $9.99 \pm 0.34$ \\
\hline RBW & $23.45 \pm 0.49$ & $52.50 \pm 4.32^{\mathrm{b}}$ & $9.98 \pm 0.33$ \\
\hline LBW & $23.81 \pm 0.44$ & $55.72 \pm 3.34^{\mathrm{ab}}$ & $10.09 \pm 0.19$ \\
\hline HBW & 0.065 & 0.011 & 0.283 \\
\hline$P$ value & $23.31 \pm 0.58$ & $54.90 \pm 3.99$ & $9.80 \pm 0.20^{\mathrm{b}}$ \\
\hline Effect of betaine supplementation & $55.69 \pm 4.14$ & $10.24 \pm 0.16^{\mathrm{a}}$ \\
\hline Betaine $0 \%$ & $23.68 \pm 0.52$ & 0.545 & $0.281 \times 10^{-6}$ \\
\hline Betaine $0.14 \%$ & 0.066 &
\end{tabular}

a,b Different superscripts in the same column indicated significant difference $(\mathrm{P}<0.05)$.

RBW: Random body weight, HBW: High body weight, LBW: Low body weight.

Table 3. Effect of divergent selection based on body weight and betaine supplementation on feed and nutrient efficiency of Japanese quail.

\begin{tabular}{|l|c|c|c|}
\hline Treatments & $\begin{array}{c}\text { Feed Efficiency } \\
(\%)\end{array}$ & $\begin{array}{c}\text { Protein Efficiency } \\
\text { Ratio }\end{array}$ & $\begin{array}{c}\text { Energy Efficiency } \\
\text { Ratio }\end{array}$ \\
\hline Interaction between body weight and betaine supplementation \\
\hline Random $\times$ betaine $0 \%$ & $24.5 \pm 1.21$ & $1.23 \pm 0.06$ & $8.75 \pm 0.43$ \\
\hline Random $\times$ betaine $0.14 \%$ & $24.83 \pm 1.67$ & $1.24 \pm 0.08$ & $8.87 \pm 0.60$ \\
\hline LBW $\times$ betaine $0 \%$ & $21.47 \pm 0.82$ & $1.07 \pm 0.04$ & $7.67 \pm 0.29$ \\
\hline LBW $\times$ betaine $0.14 \%$ & $23.18 \pm 2.73$ & $1.16 \pm 0.14$ & $8.28 \pm 0.97$ \\
\hline HBW $\times$ betaine $0 \%$ & $22.99 \pm 2.05$ & $1.15 \pm 0.10$ & $8.21 \pm 0.73$ \\
\hline HBW $\times$ betaine $0.14 \%$ & $24.07 \pm 0.74$ & $1.2 \pm 0.04$ & $8.6 \pm 0.26$ \\
\hline$P$ value & 0.663 & 0.661 & 0.661 \\
\hline Effect of body weight & $24.67 \pm 1.39^{\mathrm{a}}$ & $1.23 \pm 0.07^{\mathrm{a}}$ & $8.81 \pm 0.50^{\mathrm{a}}$ \\
\hline Random & $22.32 \pm 2.10^{\mathrm{b}}$ & $1.12 \pm 0.11^{\mathrm{b}}$ & $7.97 \pm 0.75^{\mathrm{b}}$ \\
\hline LBW & $23.53 \pm 1.56^{\mathrm{a}, \mathrm{b}}$ & $1.18 \pm 0.08^{\mathrm{a}, \mathrm{b}}$ & $8.4 \pm 0.56^{\mathrm{a}, \mathrm{b}}$ \\
\hline HBW & 0.017 & 0.015 & 0.017 \\
\hline$P$ value & $22.99 \pm 1.86$ & $1.15 \pm 0.09$ & $8.21 \pm 0.66$ \\
\hline Effect of betaine supplementation & $1.2 \pm 0.09$ & $8.58 \pm 0.67$ \\
\hline Betaine $0 \%$ & $24.03 \pm 1.89$ & 0.097 & 0.104 \\
\hline Betaine $0.14 \%$ & 0.105 &
\end{tabular}

${ }^{\mathrm{a}, \mathrm{b}}$ Different superscripts in the same column indicated significant difference $(\mathrm{P}<0.05)$.

The effect of bodyweight selection indicated that HBW tended to enhanced feed intake compared with other bodyweight clusters $(\mathrm{P}=0.065)$, which might be associated with the requirement to meet the energy and other nutrients in HBW quails. On the other hand, the LBW quails require less energy. Thus, the feed intake was tended to be lower. Following this, the higher feed intake is used to fulfill the energy requirement [17,18]. Nestor et al. [19] found differences for egg production in three different quail groups that supported the finding 
of this study. The LBW group generated the lowest egg production, although it did not differ from HBW, indicating that the LBW quails are not suitable for egg production. Taskin et al. [3] observed that HBW quails generated higher egg production than LBW, which is slightly different from this study. Changes in egg production due to bodyweight selection were not associated with similar changes in the number of follicles produced by the ovary [19]. In addition, other studies indicated that high body weight line quails had heavier eggs than low body weight line [20,5,21].

Furthermore, betaine supplementation increased the egg weight but did not affect other variables. The increase in egg weight due to betaine supplementation indicating improvement in the nutrient utilization for egg production. Betaine supplementation has been shown to increased protein synthesis and decreased protein degradation [22]. Following this finding, studies in laying poultry showed improved performance traits due to betaine supplementation, including egg weight [7,10]. Furthermore, Ratriyanto et al. [7] observed that supplementation of $0.12 \%$ betaine to methionine adequate diet enhanced quails' egg quality traits, including the yolk, albumen, and eggshell weight.

There was no interaction identified between body weight and betaine supplementation on feed efficiency and the protein and energy ratio of quails. Divergent body weight selection affects the feed efficiency, protein, and energy ratio $(\mathrm{P}<0.05)$. The LBW group showed the lowest feed efficiency, protein efficiency ratio, and energy efficiency ratio values. However, they did not differ to HBW group. This finding agreed with the lowest egg production resulted by LBW group in this study, although feed intake was not affected by the bodyweight selection. Each bodyweight cluster resulted in relatively the similar feed intake, while the LBW cluster resulted in a lower egg production than other bodyweight clusters. Consequently, the LBW has a low feed efficiency and protein and energy efficiency ratio. These results agreed with Pym and Nicholls [23], who reported that the feed conversion for high body weight was better than low body weight.

Betaine supplementation did not affect feed efficiency in quails, which might be associated with the methyl group donor content in the diet. This diet was formulated to meet the NRC [11] requirement with adequate methionine content. In agreement with this finding, Harms and Russel [24] did not find any effect of betaine supplementation on the performance of laying hens.

\section{Conclusion}

An interaction was identified between body weight and betaine supplementation on egg weight, in which betaine increased egg weight in all body weight clusters. Random body weight produced more eggs and a highest feed efficiency than Low body weight, although the result was not differed to High body weight. Betaine supplementation enhanced egg weight than non-supplemented group. Random and High body weight and betaine supplementation can be applied to optimize the performance of quails in a tropical environment.

\section{References}

1. M.M. Shanaway, Quail Production Systems: A Review (FAO, Rome, 1994)

2. H. Lin, H.C. Jiao, J. Buyse, and E. Decuypere, Worlds. Poult. Sci. J. 62, 71 (2006)

3. A. Taskin, U. Karadavut, R.I. Tunca, S. Genc, H. Cayan, Indian J. Anim. Res. 51, 358 (2017)

4. M. Baylan, Rev. Bras. Cienc. Avic. 19, 623 (2017)

5. S. Alkan, M. Mendeş, K. Karabağ, M.S. Balcioğlu, Arch. Fur Geflugelkd. 73, 124 (2009) 
6. B.U. Metzler-Zebeli, M. Eklund, R. Mosenthin, Worlds. Poult. Sci. J. 65, 419 (2009).

7. A. Ratriyanto, S. Prastowo, J. Therm. Biol. 18, 80 (2019)

8. S.O. Park, W.K. Kim, Poult. Sci. 96, 1212 (2017)

9. N. Chand, S. Naz, H. Maris, R.U. Khan, S. Khan, M.S. Qureshi, Pak. J. Zool. 49, 1857 (2017)

10. Y.A. Attia, A.E.E. Abd-El-Hamid, A.A. Abedalla, M.A. Berika, M.A. Al-Harthi, O. Kucuk, K. Sahin, B.M. Abou-Shehema, Springerplus 5, 1619 (2016)

11. Nutrition Research Council, Nutrient requirements of poultry, 9th ed. (National Academic Press, Washington DC, 1994)

12. A. Ratriyanto, R. Mosenthin, D. Jezierny, M. Eklund, J. Anim. Physiol. Anim. Nutr. (Berl). 94, 788 (2010)

13. A. Ratriyanto, F. Firmanda, H. Purwanti, M. Murjoko, Turkish J. Vet. Anim. Sci. 44, 350 (2020)

14. R Core Team, R: A Language and environment for statistical computing (R Foundation for Statistical Computing, Vienna, 2019)

15. A. Ratriyanto, R. Indreswari, R. Dewanti, S. Wahyuningsih, IOP Conf. Ser. Earth Environ. Sci. 142, (2018)

16. A. Ratriyanto, R. Indreswari, A.M.P. Nuhriawangsa, Rev. Bras. Cienc. Avic. 19, 445 (2017)

17. A.V. Elangovan, A.B. Mandal, P.K. Tyagi, P.K. Tyagi, S. Toppo, T.S. Johri, J. Sci. Food Agric. 84, 2028 (2004)

18. S. Kaur, A. Mandal, K.B. Singh, Livest. Sci. 117, 255 (2006)

19. K.E. Nestor, W.L. Bacon, A.L. Lambio, Poult. Sci. 62, 1548 (1983)

20. S. Alkan, K. Karabăg, A. Galiç, T. Karsli, M.S. Balcioğlu, Kafkas Univ. Vet. Fak. Derg. 16, 239 (2009)

21. M.A.F. Nasr, M.S. El-Tarabany, M.J. Toscano, Anim. Prod. Sci. 56, 1797 (2016).

22. S.V. Rama Rao, V. Ravindran, T. Srilatha, A.K. Panda, M.V.L.N. Raju, J. Appl. Poult. Res. 20, 528 (2011)

23. R.A.E. Pym, Br. Poult. Sci. 20, 73 (1979)

24. R.H. Harms, G.B. Russell, Poult. Sci. 81, 99 (2002) 